\title{
THE NORTH-EASTERN BORDER OF THE CELTIC WORLD
}

\author{
VÁCLAV BLAŽEK
}

\section{Introduction}

The present study provides an etymological analysis of toponyms collected by Ptolemy from Northeast Europe, as known to him in the midsecond century CE. The territory studied roughly corresponds to contemporary Poland and part of the Czech Republic. The toponyms are taken from editions of Ptolemy by Šimek 1930 and Nobbe 1966.

\section{Etymological glossary}

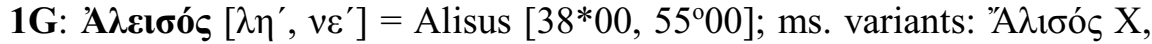

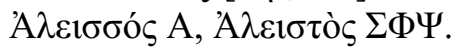

Germanic *alizō $\sim$ *alisō f. $>$ Gothic *alisa 'alder' > Spanish aliso id., Old Saxon elira id., elis- (in compounds), Old High German elira, erila id. Cf. also Old Norse elri n. < *alizja-, alri n. < *aliza- (Orel 2003: $15)$.

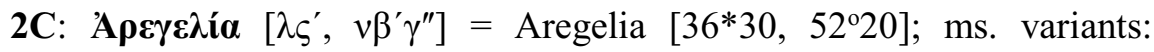

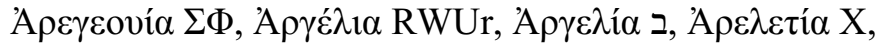

Celtic *arei-geliā 'by white (river)', cf. Gaul. are Sequania rijos 'by the river Sequania' (inscription from St-Germain-Sources-Seine, Lambert 2003: 99), it is also found in numerous proper names as $A r \bar{e}-$ morici gl. antemarini (glossary of Vienne - see Lambert 2003: 206), Apๆ-

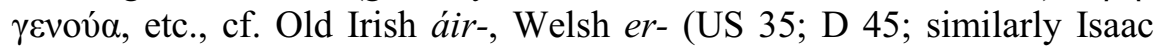
2004), and Irish gel 'white, fair, bright, shining' (DIL G 58-59; US 112). The toponym has been identified with the Czech city Teplice on the river Bilina, the left tributary of the Elbe/Labe, etymologizable from Czech bily 'white'.

3E: Арбикоv́ $\boldsymbol{\alpha}\left[\mu \alpha^{\prime} \gamma\right.$ ó $\left.^{\prime \prime}, \mu \theta^{\prime}\right]=$ Arsicua $\left[41^{*} 40,49^{\circ} 00\right]$; ms. variants: Арбıкои̃ $\alpha \operatorname{UrtAD} \Delta \mathrm{M} \Omega \mathrm{S} \Sigma \Phi \Psi$.

Perhaps an Old European compound ${ }^{*} H_{1} r s i-H_{2} \hat{k^{\prime \prime}}-e H_{2^{-}}$'flowing water(s)', where the first component is derivable from the verb ${ }^{*} H_{1}$ ers - 'to flow', Cf. Old Indic árșati, Hittite āraszi 'flows' (LIV 241; Pokorny 1959: 336-7; Krahe 1964: 47), and the latter one from the zero-grade of IE ${ }^{*} H_{2} e \hat{k}^{u}$ - (Pokorny 1959: 23) > Latin aqua 'water, Wasserleitung', ?Venetic NL Aquileia; Celtiberian *akua attested in the Third bronze from Botorrita in the syntagm Ta.r.a.Ku.a.i, which is interpreted by de 
Bernardo Stempel (2007: 58) as tar akuai 'through the water' or 'along the water', where akuai is the dat. sg. of the $\bar{a}$-stem; Germanic *ahwo > Gothic aha f. 'river, body of water', etc. (Kroonen 2013: 7).

4E: Apбóvıov $\left[\mu \gamma^{\prime}, v \beta^{\prime}\right]=$ Arsonium $\left[43^{*} 30,52^{\circ} 20\right]$; ms. variants:

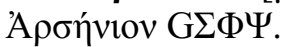

Old European ${ }^{*} H_{1} r s-o n$ - from the verb ${ }^{*} H_{1}$ ers- 'to flow'. Cf. Old Indic árșati, Hittite āraszi 'flows' (LIV 241; Pokorny 1959: 336-7; Krahe 1964: 47).

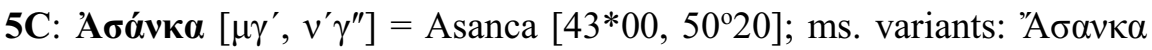
$\operatorname{FS} \Sigma \Phi \Psi, A \sigma \alpha ́ v \delta \alpha \mathrm{X}$.

Celtic *asnakā, cf. Old Irish asnach 'flank walls', lit. 'ribbed', coll. from asna 'rib', Welsh asen 'rib; beam' (DIL A-434; LEIA A 94-5; US 24).

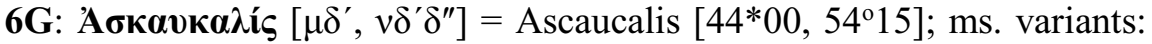

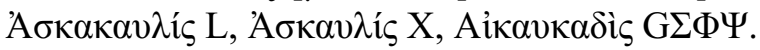

With respect to the variant $\mathrm{L}$ the emendation *aska-kaul ${ }^{\circ} \rightarrow{ }^{*}$ aska$k a \beta l^{\circ}$ seems possible. It is perhaps thinkable to propose a compound of Germanic *aska- m. 'ash' (Kroonen 2013: 38) \& *kabla/ōn- 'piece of wood' (Kroonen 2013: 276-7).

Note: The vacillation $-\alpha v-\sim-\alpha \beta$ - appears e.g. in the toponym ’Avavov 'Av $\alpha \beta$ ov [Ptol. II, 11.30].

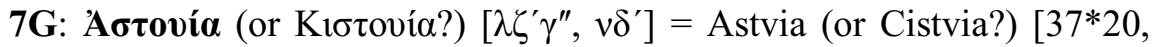

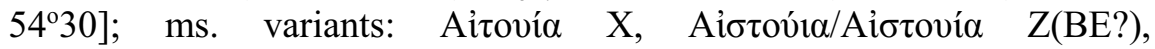

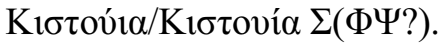

Germanic *astaz m. > Goth asts 'branch, bough', Old Saxon ast id., OHG ast id. or *astaz m. > Old English ast 'kiln', Middle Dutch ast id. In the case of the variant with the initial diphthong a good candidate is Germanic *aista/ō- > Old English āst m. 'oven', Middle Low German eiste f. 'oast house', Middle Dutch eest 'drying kiln' (Kroonen 2013: 14).

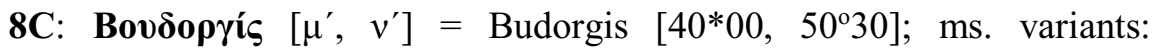

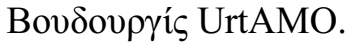

Celtic *budo- 'victory' \& *rīgo- 'power, government'. Cf. Old Irish búaid 'victory', Old Breton bud gl. bradium, Old Welsh budicaul gl. victo, Welsh budd 'profit' and Old Irish rige 'ruling, kingship, sovereignty' (DIL B-221; R-67 for *rīgiāa; LEIA B-107; R-25; Falileyev 2000: 20; see Sims-Williams 2006: 189). 


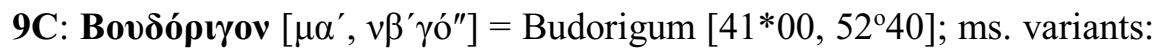

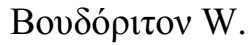

Celtic *budo- 'victory' \& *rīgo- 'power, government'. Cf. Old Irish búaid 'victory', Old Breton bud gl. bradium, Welsh budd 'profit' and Old Irish rige 'ruling, kingship, sovereignty' (DIL B-221; R-67 for *rīgi $\bar{a}$; LEIA B-107; R-25).

10G: Bovvítıv $\left[\lambda \theta^{\prime}, v \varepsilon^{\prime}\right]=$ Bunitium $\left[39^{*} 30,55^{\circ} 30\right]$; ms. variants: Movvítiov X, Bovpítiov $\Phi$.

Germanic, cf. Old English bune 'Ried, Rohr', English dial. bun 'hohler Stengel', Norwegian, Icelandic buna 'Beinröhre' (Holthausen 1963: 38). The suffixal extension probably corresponds to West Germanic *bil-epja- 'image, likeness' > Old Saxon bilithi, Old Dutch bilithe, Old High German biladi, biledi, German Bild; or *iw-epja- n. > Swedish ide 'yew grove' vs. Germanic *īwa- m. 'yew' (Kroonen 2013: 64, 271).

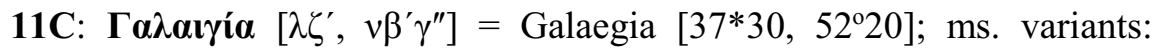

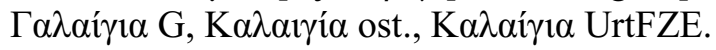

?Celtic: $c f$. Nomen Loci Calaico in pago Wapencense (AD 739) (Holder I: 688: Diplomata, ed. Pardessus).

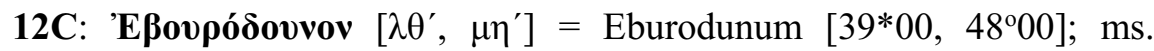

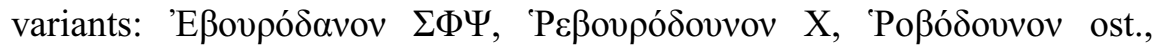
'Podóßouvov RWC.

Celtic *eburo- 'yew-tree'. Cf. Gaulish *eburos, Old Irish ibar, later iubar, iobar 'yew' (DIL I-41), Breton evor 'bourdaine', Gaulish e.g. NL Eburodunon, today Yverdon in Switzerland, etc. (Holder II: 1395-404; D 134). The second component corresponds to Gaulish *dünon in

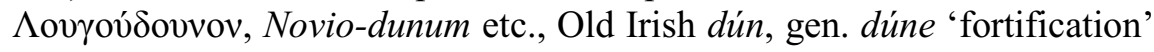
(US 207; 150).

13C: "Eßovpov $\left[\mu \alpha^{\prime}, \mu \theta^{\prime}\right]=$ Eburum $\left[41^{*} 00,49^{\circ} 30\right]$; ms. variants: "Eßovvov Rt.

Celtic *eburo- 'yew-tree'. Cf. Gaulish *eburos, Old Irish ibar, later iubar, iobar 'yew' (DIL I-41), Breton evor 'bourdaine', Gaulish e.g. NL Eburodunon, today Yverdon in Switzerland, etc. (Holder II: 1395-1404; D 134).

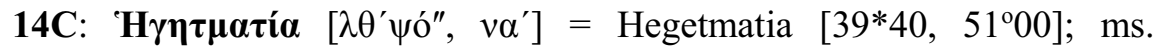

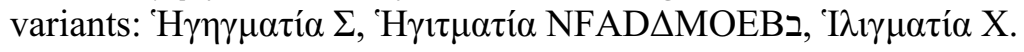

Celtic *Segetā-matiā gl. dea Segeta et bona, cf. deae Segetae, Aquae Segetae by Montbrison (Holder II: 1440), also Old Irish maith 'good' (DIL M-43-45; LEIA M-12-13); to explain the loss of the initial $s$

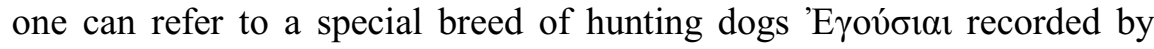


Arrianus who connected the dogs with the tribe Segusiavi (Holder II: 1453-5).

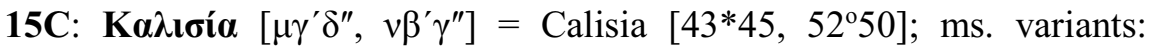

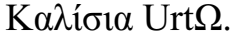

Perhaps Celtic (Holder III: 1048), maybe related to Old Irish caile m. 'spot' < *kalio- (Matasović 2009: 186); cf. the suffix -isia: Alisia,

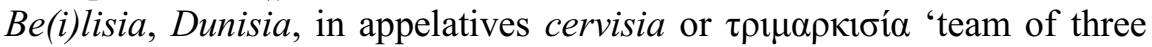
horses' (Holder II: 79).

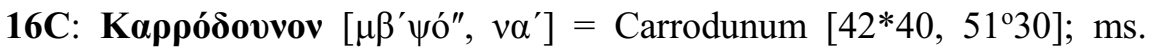
variants: Kpódovvov VPF.

Celtic *karro-dūnon 'stone fort' or ?'wagon-fort': cf. Gaulish carrus - epithet of Mars, preserved in the name of the mountain, today called Pic-du-Gar (Holder I: 815-6), Middle Welsh carrec 'stone', Old Irish carrac 'rock, large stone', less probably the first component corresponds to Gallo-Latin carrus 'wagon', Middle Welsh carr 'vehicle', Old Irish carr 'cart, wagon' (DIL C-78 \& 77; LEIA C-41-42; US 72). The

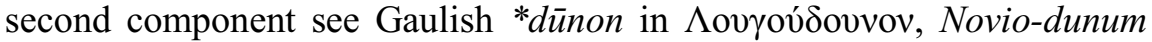
etc., Old Irish dún, gen. dúne ‘fortification' (US 207; 150).

17C: Kaбovpyís $\left[\lambda \theta^{\prime} \delta^{\prime \prime}, v^{\prime} \varsigma^{\prime \prime}\right]=$ Casurgis $\left[39^{*} 15,50^{\circ} 10\right]$; ms. variant Kaбoujis W.

Celtic *kasso-uorg 'built from the twisted [walls]', cf. Old Irish casaid 'twists, bends' (DIL C-82-83; LEIA C-44) and do(f)airci 'towers over, surpasses, excels' (DIL D-263), Old Breton guerg gl. 'efficax'.

18Г: Kovvónvov $\left[\lambda \lambda^{\prime} \gamma^{\prime \prime}, v \varepsilon^{\prime}\right]=$ Coenoënum [36*20, 5530]; ms. variants:

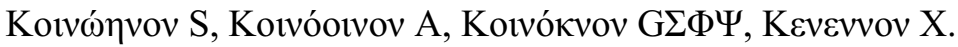

Perhaps a Greek compound of kovvós 'common' and ivvíov 'bit, rein' [Pollyx1.148], the diminutive implying the noun $\tilde{\eta}$ vov (LS 652).

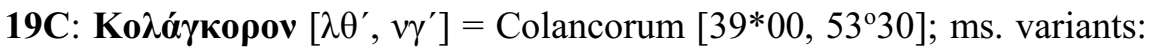

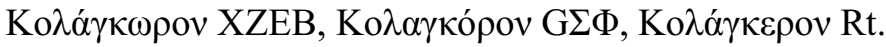

Celtic *kolani-: Old Irish colainn 'body, flesh; corpse, carcass, trunk', in laws 'principal, capital; substance of which an article is made' etc. (DIL C-322), Middle Welsh kelein, keleyn, pl. calanedd 'cadavres,

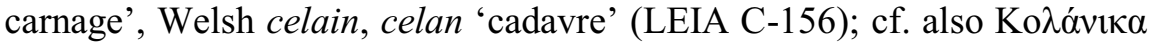
'a city of Damnonii by the spring of the Clyde' [Ptolemy II, 3. 7] = Colanica [Ravennatis V 31. 7] (Holder I: 1064), plus Celtic *koro-, attested in Old Irish cor m. 'act of putting, casting; a throw', do-cuirethar 'to put, place', with derivatives as cora 'palissade, mur de pierres, gord à 
poisson, pêcherie', dat. coraid, Welsh cored f. 'gord, barrage, vivier', Old Breton coret < *koret-s. Without the dental extension see Old Irish Sescend in da Cor 'moor of the two hillocks', Breton aval-gor 'champ de pommiers', Welsh Ban-gor 'paroi de branches tressées, clôture' = Irish Benchuir etc. (LEIA C-204-206).

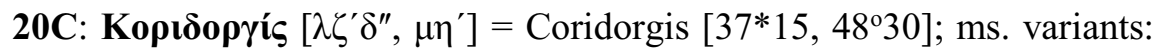

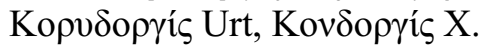

Celtic *kori-dorg' 'kept by army', cf. Old Irish cuire 'troop, company', Welsh cordd 'tribe, clan, troop', Gaulish Corio-solites, Tricorii, Petru-corii etc. (DIL C-597; LEIA C-275; Schmidt 1957: 183) and Breton derchell 'to keep' (US 149).

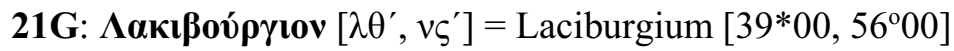

Probably formed from Germanic *lekjōn- f. > Faeroese loekja 'well, waterhole, waterspout', Norwegian laekje 'rivulet, wooden water-pipe' (Kroonen 2013: 331) with the typical Northwest Germanic change ${ }^{*} \bar{e}>$ $* \bar{a}$ or from some derivative of the Germanic verb *lakjan- 'to cause to leak, moisten' > Old English leccan, Old High German lecken id. (Kroonen 2013: 325).

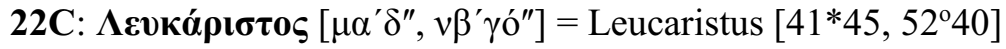

Celtic: cf. Brittonic NL Leucaro (Itin. Ant.) = Welsh Cas Llychwr; Gaulish NL Leuceris (Geog. of Ravenna) between Bergamo and Brescia, today Lecco (Holder II: 192-3; D 169). The extension in *-isto- can be interpreted as the superlative.

23C: $\Lambda$ í $\mu 10 \varsigma$ ä $\lambda \sigma o \varsigma\left[\mu \alpha^{\prime}, v \gamma^{\prime}\right]=$ the grove of Limis $\left[41^{*} 00,53^{\circ} 30\right]$; ms.

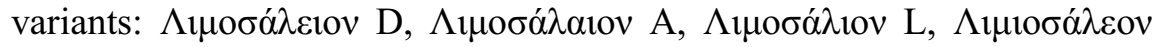

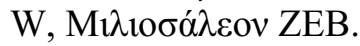

Connected with the Celtic designation of 'elm': Gaulish ethnonym Lemo-uices $>$ Limoges, place-names as Limours $<$ *lemausum, Limeuil $<$ *lemo-ialum, personal names Lemisunia, Lemiso etc.; Brittonic *lèmā- > Middle Welsh, Welsh sglt. llwyfen 'elm', pl. llwyf; Goidelic *limo- > Middle Irish lem m. (Holder II: 175-82, 226-7; Billy 1993: 93; Delamarre 2001: 168; Matasović 2009: 237: nom. ${ }^{*} H_{l} l e i \bar{\alpha} \bar{m}$ : gen. $\left.{ }^{*} H_{l} l i m o s\right)$.

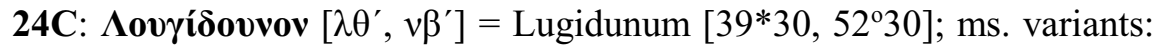

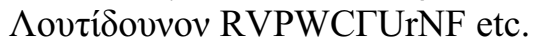

Celtic *lugi-dūnon 'fort of the (tribe) Lugii' (Holder II: 306) or 'fort of the treaty', cf. Old Irish lugae, later luige 'oath, swear' (DIL L-239),

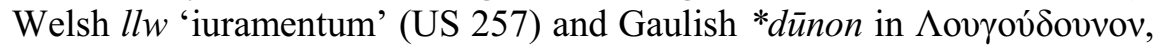


Novio-dunum etc., Old Irish dún, gen. dúne 'fortification' (US 207, 150; Sims-Williams 2006, 191).

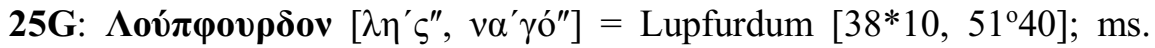

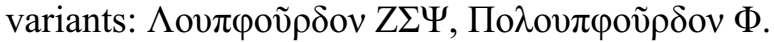

Old European hydronym *Lup(iā) (Lupia by Mela III, 30; Tacitus, Annales I, 60; see Krahe 1964: 99-100) and Germanic furđu- 'ford', cf. Norwegian ford 'path through a swamp', Old English ford, Old High German furt 'ford', i.e. 'ford across the river Lupia' (WGS 230).

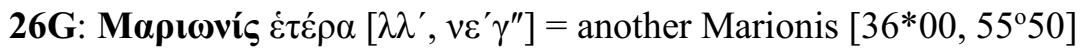

Probably derived from Germanic *mari- m./n. 'lake, sea' > Gothic mari-saiws, Old Norse marr, Old English mere, Old High German meri or *marīn- id. > Gothic marei, Old Saxon meri, Old High German merī id. (Kroonen 2013: 354-5). In this case perhaps 'near the sea'.

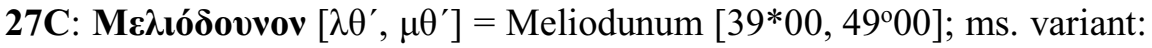

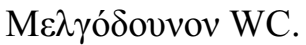

Celtic *medio-dūnon? 'middle fort' (Schwarz 1931: 17): Gaulish

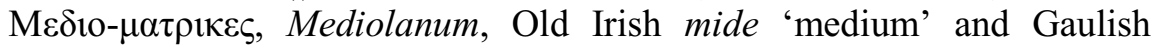

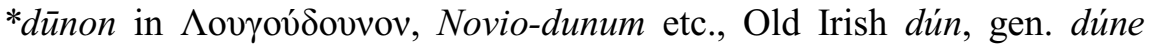
'fortification' (US 207; 150).

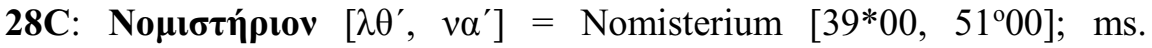

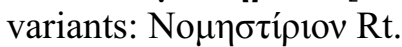

Celtic *nomi-stērio- 'temple of a (goddess) star' (= ? *Stēronā, corresponding to Gaulish Sirona/Dirona, see D 239): Old Welsh nom gl. templa (US 192; Falileyev 2000: 121).

29B?: Oỏípovvov $\left[\mu^{\prime}, v \varepsilon^{\prime}\right]=$ Virunum $\left[40^{*} 30,55^{\circ} 00\right]$; ms. variant: 'Ioúpovvov Rt.

Undoubtedly connected with the ethnonym Oủıovvoí (S), Oủpoṽvor (R), mentioned by Ptolemy in $\S$ II, 11.17. With regard to the homonymous name of the town from Noricum, attested as Virunum [Pliny III, 146], Ovípovvov [Ptol. II, 11.17], but by other authors as Varunum [It.

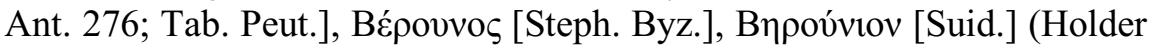
III: 399), it is legitimate to admit a different primary vocalism in the topo$\&$ ethnonym from North Germania too. There are several hypothetical alternative solutions:

(a) If it was *Oóźpovvov \& *Oỏepovvoí, a relation to the 'Old European' hydronym Veruna (1379; Dép. Var, France - see Krahe 1964: 39) would be possible. 
(b) In the case of *Oóápovvov \& *Oỏapovvoí a connection with the ethnonym Varini [Tacitus, Germania 40], Varinnae [Pliny IV, 99], Aủapıvoí [Ptol. III, 5.8], besides Aü $\alpha \rho \pi o 1$ [Ptol. II, 11.9], Oủ $\alpha \rho v o 1$ [Proc. b. G. II, 15.2; III, 35.15; IV, 20.1], Varni [Jord. Getica 117.13] (Schönfeld 1911: 257-8) seems the most natural solution (Bremer 1899: 91; Šimek 1935: 153-7).

(c) With respect to the variant 'Iov́povvov (Rt) it is tempting to think about its Baltic origin. There is a common Baltic term 'sea' attested in numerous variants in all Baltic languages: Prussian iūrin [K III, 67, 11] = /jūrian/,

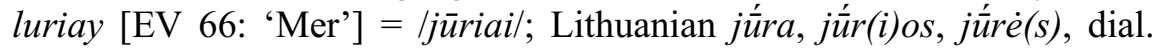
juriai 'sea', besides jurēžeris 'a very big lake', Latvian jüra(s) \& jüra(s), jüre(s), jùre, jūris 'sea; a big lake' (Toporov 1980: 93-4). The suffix *-ūnappears e.g. in the Prussian river-name Raudune (1316), without the suffix the Lithuanian river-name Raudà, both from raũdas 'reddish'; similarly the Prussian lake-name Sirgun : sirgis 'stallion'; Lithuanian Dumbliūnai : dum̃alas 'marsh' (Gerullis 1922: 139, 254).

30G: Ov̉ıítıv $\left[\mu \alpha^{\prime}, v \delta^{\prime}\right]=$ Viritium $\left[41^{*} 00,54^{\circ} 30\right]$; ms. variants: Oủipov́

There are at least three hypothetical Germanic etymologies:

(a) Germanic *wir-epja- > Old High German wiridi-bora f. 'freeborn' (the latter component is derived from the verb beran 'to bear'), hence 'place of free men'? or so.

(b) Germanic *werila/ō f. > Gothic wairila 'lip', Old English pl. weleras id., a diminutive of *werō- > Old Frisian were f. 'lip' (Kroonen 2013: 580; Orel 2003: 456). This solution is applicable in the case of emendation $\tau \imath \rightarrow \lambda$.

(c) Germanic *waripa-/*warupa- > Old English warop, wearop, wearp n. 'shore, bank', Middle Low German werde 'dammed up land', Old High German warid, werid, Middle High German wert, gen. werdes m. 'elevated waterless land between swamps; island, shore' (WGS 395). This solution implies the umlaut $a \ldots i>e \ldots i$, perhaps comparable with the river-name 'E $\lambda$ í $\sigma \omega v$ by Dio Cassius 54, 33.4, corresponding to the military camp Aliso by Velleius Paterculus II, 120.4 and the fortress Aliso by Tacitus, Annales II, 7.

31C: $\Pi \boldsymbol{\alpha \rho} \mathbf{\varepsilon} \varepsilon v v \boldsymbol{\alpha}\left[\mu \beta^{\prime}, \mu \theta^{\prime} \gamma^{\prime \prime}\right]=$ Parienna $\left[42^{*} 00,49^{\circ} 20\right]$

It is derivable from the Celtic word for 'cauldron' on the basis of metaphor 'cauldron' $\rightarrow$ 'basin, hollow, bowl', cf. Gaulish *parioreconstructed after Provençal par, Lyonnaise per, Italian dial. of Ferrara, Pavia per 'kettle' (Meyer-Lübke 1935, \#6246; Billy 1993: 118), Middle Welsh pair, Welsh peir, Cornish per gl. 'lebes', Old Irish coire m. < 
Celtic * * $k^{u}$ ario- $<* k^{u}$ rio- (Delamarre 2001: 208-9; LEIA III: C-153; Matasović 2009: 175), extended by the suffix *-enna, attested in many Gaulish place-names, e.g. Anduenna, Ardu(i)enna, Arguenna, Bagenna, Boudenna, Tarvenna, etc. (Holder I: 1439).

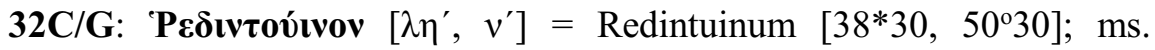

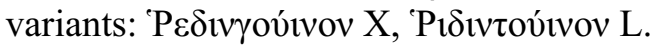

Celtic *rēdi(o?)-dūnon 'fort of riders' (Schwarz 1931: 17) > Germanic *rēđi-tūna-; the Celtic stem *rēdi- is preserved e.g. in the Gaulish compound eporediae interpreted as boni equorum domitores in

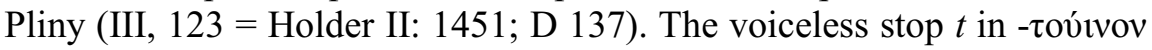
indicates that original Celtic *dūnon was already replaced by Germanic *tūna- > Old Nordic tún, Old English and Old Saxon tūn, Old High German zūn 'fence, hedge' etc. (Kluge \& Seebold 1999: 904).

33G: 'Pov́

Probably connected with the ethnonym Rugii belonging to the East Germanic tribe preceding Goths in the area around the mouth the Vistula river [Tacitus, Germania 44; Jordanes, Getica 26].

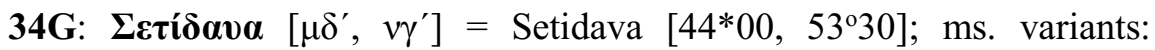

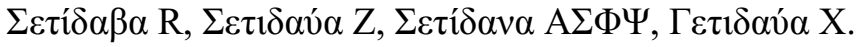

A compound of East Germanic *sēti- 'pasture; possible to sit down' $>$ Old Norse saetr 'summer pasture; suitable for sitting on', plus compounds as Gothic anda-sets, Old English and-scete 'odious, hateful', Middle Dutch ant-set id., Middle High German ant-seze 'brave' (de Vries 1962: 576; Kroonen 2013: 433; Orel 2003: 326) \& *dawwa/ō- 'dew' > Old Norse dogg, Old English dea w, Old Frisian daw, Old Dutch dou, Old High German tou (Kroonen 2013: 91). Originally perhaps 'pasture/sitting on dew' $\rightarrow$ 'damp pasture/place'. The difference *sēti- vs. *sāti- (see

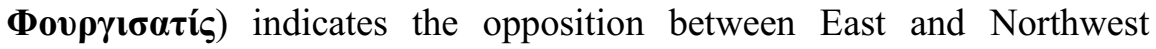
Germanic respectively already in the mid of the 2 nd cent. CE.

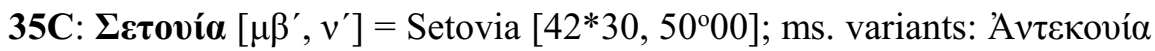
Urt.

Accepting the replacement $\tau \rightarrow \gamma$, it is possible to derive it from Celtic *sego- 'firm, power(ful)' > Middle Irish seg m. 'force, strength, heed, interest', Middle Welsh hy 'bold, brave' (LEIA S-68; US 297; Matasović 2009: 327); cf. Hispano-Celtic NL in Hispania Tarraconensis:

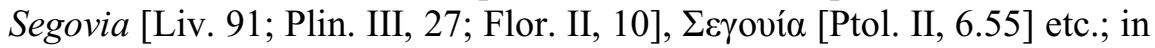
Hispania Baetica: Segovia [Hirt. b. Alex. 57.6]; Balkano-Celtic in Dalmatia: $\Sigma \varepsilon \gamma o v i ́ \alpha$ [Appian, Illyr. 27] (Holder II: 1452-3). Concerning the 
suffix -via, cf. Gergovia, Iuvavia, Nemavia, Vinovia, Vosavia etc. (Holder III: 273).

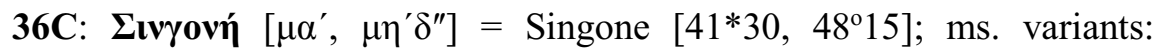

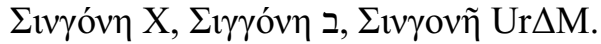

In continental Celtic onomastics there are numerous forms derivable from the stem *sing(i)-: NL Singiacus $\rightarrow$ castle Cingé in Touraine, dep. Indre-et-Loire, Singilia in Baetica, Singidunum - today Beograd - the capital of Serbia; NM Singenia in Aouste by Crest, dep. Drôme, Singeria in Carantania, etc. (Holder II: 1570-3; Billy 1993: 137). In Insular Celtic there are two hypothetical alternative cognates: (a) Old Irish seng 'thin'; (b) Old Irish séig, gen. séga 'bird of prey, falcon' (LEIA S-85-86; S-71; Delamarre 2001: 233). The place-name inspired by 'falcon' is apparently more attractive and so more probable, but the first possibility cannot be excluded at all.

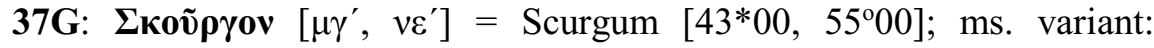
$\Sigma \kappa o v ́ \rho \gamma o v$ Urt.

Accepting the frequent replacement $\gamma \rightarrow \tau$, it is possible to identify here Germanic *skurta- 'short' (Orel 2003: 346).

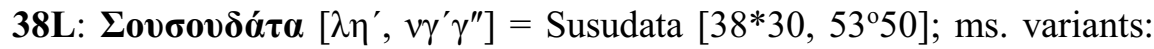

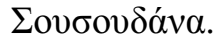

Latin *sub Sudeta 'under the Sudeta [mountains]' (Much 1897: 99; Schwarz 1931: 24; Šimek 1935: 34). The final -êta may be interpreted as the plural to the sg. forms in -êtum, serving to designate places with certain characteristic features, e.g. asprētum 'rough place' : asper 'rough, uneven', glabrēta 'bare places' : glaber 'bald, smooth', saxētum : saxum 'rock'; frequently to designation of occurrence of concrete trees or other plants, e.g. arundinètum 'thicket of reeds': arundō 'reed, cane', ficētum 'fig-plantation' : ficus 'fig-tree', nucētum 'a wood where nut-trees grow' : nux 'nut', querquētum \& quercētum 'oak-forest' : quercus 'oak', vìminètum 'willow-copse': vìmen 'pliant twig, withe' etc. ( $c f$. Brugmann 1906: 414, $\$ 307 \beta ; 624, \S 493)$. The root proper may be identified in Latin sudes (pl. to sudis 'stake, pile'), glossed also as 'saxae' [Appuleius, Metamorphoses VII: p. 195, 26], or 'fraxineasque aptare sudes' [Vergilius, Georgica II: 359], see LD 778, 1790. The latter context implies that $\Sigma o v ́ \delta \eta \tau \alpha$ öp $\eta$ might be a Latin equivalent of the Germanic

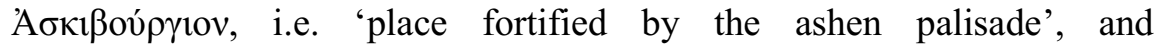
$\Sigma o v \sigma o v \delta \alpha ́ \tau \alpha=$ Latin *sub Sudetta was an area under this fortification.

39C: $\Sigma \tau \boldsymbol{\tau}$ ó́yova $\left[\lambda \theta^{\prime} \gamma\right.$ ó $\left.^{\prime \prime}, v \beta^{\prime} \gamma^{\prime \prime}\right]=$ Stragona $\left[39^{*} 40,52^{\circ} 20\right]$; ms. variants: $\Sigma \tau \rho \alpha \gamma o ́ v \alpha$ ost. 
Accepting the replacement $\tau \rightarrow \gamma$, it is possible to reconstruct Celtic *stratona $\bar{a}, c f$. Middle Breton strat 'bottom, hole', Welsh ystrad 'valley' (US 313; Henry 1900: 255).

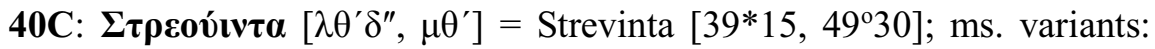

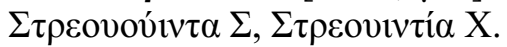

Celtic: Middle Breton strehet 'pavement of a road', Breton stréoued 'foundation of a road', Old Breton strouis 'I covered, bestrewed' (US 313; Henry 1900: 255).

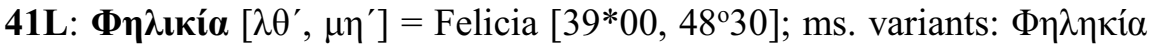

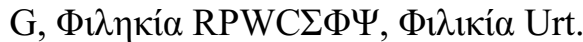

Originally 'happy things' in Latin, derived from the adj. felix 'happy'; cf. also tempora felicia 'happy times'.

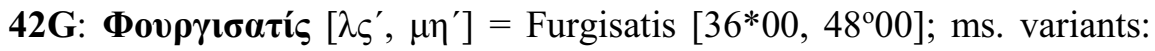

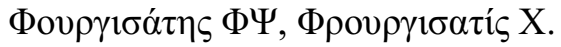

Accepting the replacement $\tau \rightarrow \gamma$, it is possible to propose West Germanic *furp/ði-sātiz 'settlement; pasture by ford' (Schwarz 1931: 28), $c f$. Germanic furdu- 'ford' > Norwegian ford 'path through a swamp', Old English ford, Old High German furt 'ford' and Old Nordic scetr 'summer meadow for cattle' (WGS 230, 427). The vowel *ā in *sātiz < Germanic *sētiz indicates a source of West (or even Northwest) Germanic provenance, in contrast to East Germanic $* \bar{e}>$ Biblic Gothic $e$.

\section{Conclusion}

1. In the area enclosed by the 36th longitude, the 48th latitude, the south coast of the Baltic sea and the Vistula river, 42 place-names (not including hydro-, oro- and ethnonyms) are mentioned in Ptolemy's work.

2. Two of these are of Latin origin, one is probably of Greek origin, in one case the Baltic etymology seems most promising and two-three toponyms may be ascribed to the so-called 'Old European' substratum. Of the remaining 36 terms the share of the Celtic and Germanic toponyms is 23 : 13 (a witness of Lautverschiebung in the case of one of the Celtic terms indicates the Celtic terms continued even after a replacement of populations).

3. The northernmost border of probable Celtic toponyms in the area of contemporary Poland may be determined between the 54th and 53rd latitudes $\left(c .53^{\circ} 30^{\prime}\right)$. 


\section{Appendix}

Place-names of Germania Magna in the East from $36^{\text {th }}$ longitude and in the North from $\mathbf{4 8}^{\text {th }}$ latitude according to Ptolemy

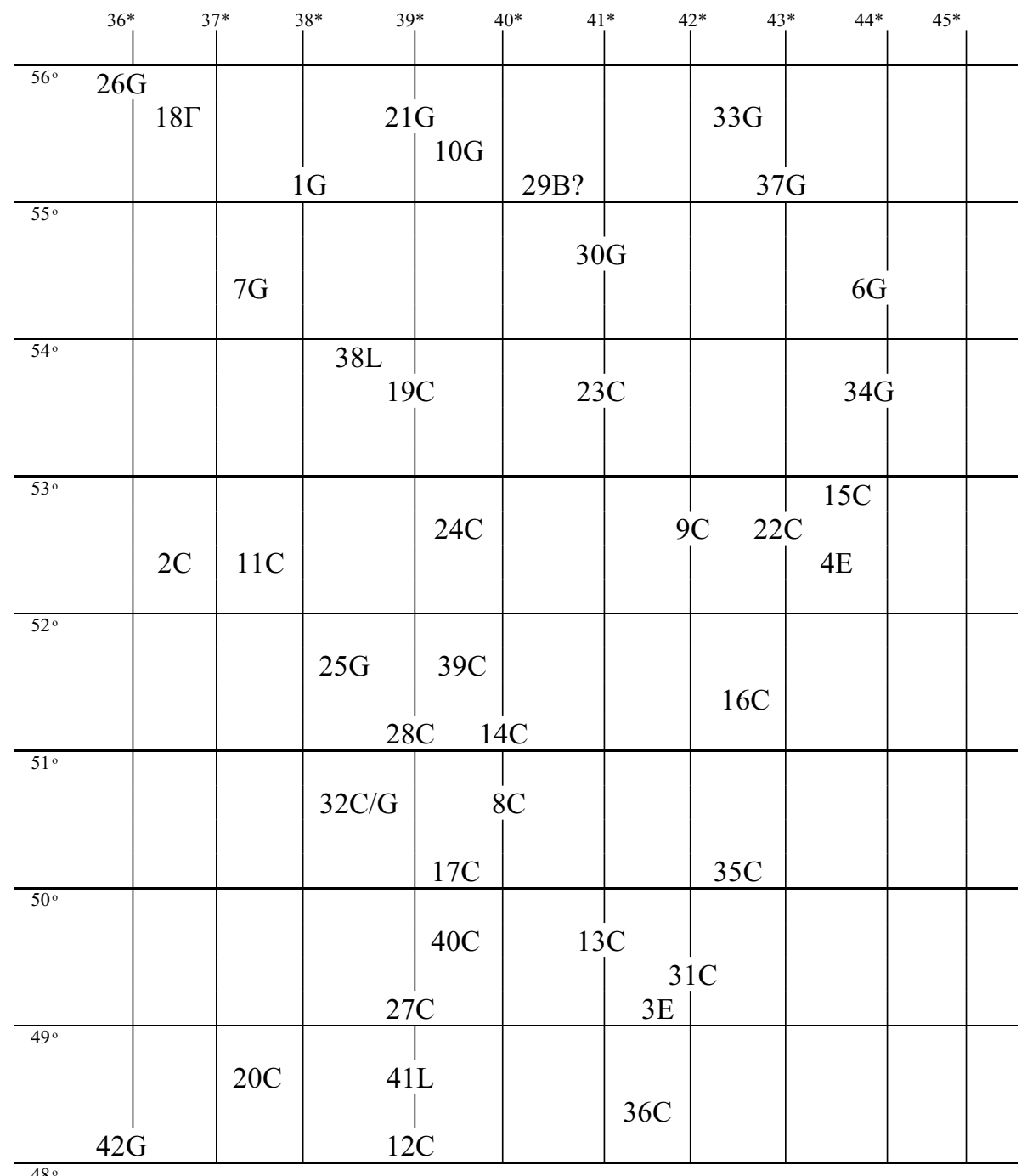

Abbreviations from this scheme: $\mathrm{B}=$ Baltic, $\mathrm{C}=$ Celtic, $\mathrm{E}=$ Old European, $\mathrm{G}=$ Germanic, $\Gamma=$ Greek, $\mathrm{L}=$ Latin. 


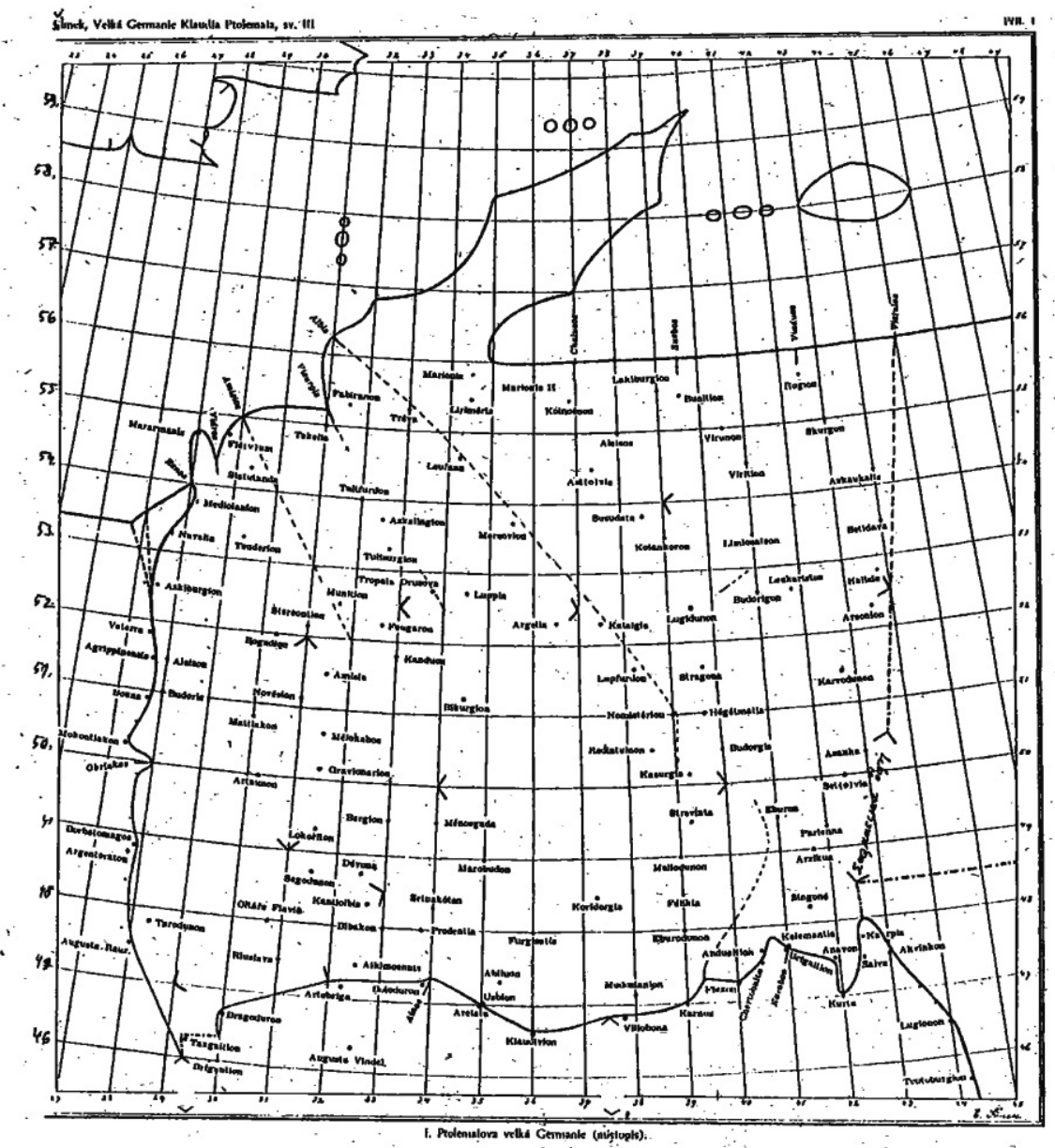

Reconstruction of the Germania Magna Ptolemy's map by Emanuel Šimek (1949) 


\section{Abbreviations}

D - Delamarre, X., 2001.

DIL - Dictionary of the Irish Language (Compact Edition), Dublin: Royal Irish Academy, 1983.

GMS - Geografický místopisný slovnik, Praha: Academia, 1993.

LD - A Latin Dictionary, Lewis, Ch. T., \& Short, Ch., Oxford: Clarendon Press, 1896.

LEIA - Lexique étymologique de lirlandais ancien (A, B, C, D, M, N, O, $\mathrm{P}, \mathrm{S}, \mathrm{T}, \mathrm{U})$, Vendryes, J. et al., eds., Dublin: Dublin Institute for Advanced Studies \& Paris: Centre National de la Recherche Scientifique, $1959 f$.

LIV - Lexikon der indogermanischen Verben. Die Wurzeln und ihre Primärstammbildungen, Rix, H. et al. Wiesbaden : Reichert, 2001.

LS - Liddell, H.G. \& Scott, R., 1901. Greek-English Lexicon. Oxford: Clarendon Press.

NL - Nomen loci.

$\mathrm{NM}$ - Nomen mulieri.

US - Stokes, W. \& Bezzenberger, A., 1894.

WGS - Falk, H. \& A. Torp, 1909.

\section{References}

Bernardo Stempel, P. de, 2007, CIb. auzu 'haurio', auzeti 'haurit', auzanto 'hauriant': Water in the Botorrita bronzes and other inscriptions and other inscriptions (K. 0.8, 1.1, 1.3, 2.1, 5.1). Palaeohispanica, 7, 5569.

Billy, P.-H., 1993, Thesaurus Linguae Gallicae, Hildesheim-Zürich-New York: Olms \& Weidmann.

Bremer, O., 1899, Ethnographie der Germanischen Stämme. Strassburg: Trübner.Brugmann, K., 1906, Grundriss der vergleichenden Grammatik der indogermanischen Sprachen, II.1. Strassburg: Trübner.

Delamarre, X., 2001, Dictionnaire de la langue gauloise, Paris: Editions Errance.

Evans, D. E., 1967, Gaulish Personal Names, Oxford: Clarendon Press.

Falileyev, A., 2000, Etymological Glossary of Old Welsh, Tübingen: Niemeyer.

Falk, H. \& A. Torp, eds., 1909, Wortschatz der germanischen Spracheinheit, Göttingen: Vandenhoeck \& Ruprecht.

Gerullis, G., 1922, Die altpreußischen Ortsnamen. Berlin und Leipzig: Walter de Gruyter. 
Henry, V., 1900, Lexique étymologique du breton moderne, Rennes: Plihon \& Hervé.

Holder, A., 1896, 1904, 1907, Alt-Celtischer Sprachschatz, I-III, Leipzig: Teubner.

Holthausen, H., 1963, Altenglisches etymologisches Wörterbuch. Heidelberg: Winter.

Isaac, G. R., 2004, Place-Names in Ptolemy's Geography: An Electronic Data Base with Etymological Analysis of the Celtic Name-Elements, Aberystwyth: CD-ROM.

Kluge, F. \& Seebold, E., eds., 1999, Etymologisches Wörterbuch der deutschen Sprache, Vols. 2, 3, Berlin - New York: Walter de Gruyter.

Krahe, H., 1964, Unsere ältesten Flussnamen, Wiesbaden: Harrassowitz. Kroonen, G., 2013, Etymological Dictionary of Proto-Germanic, LeidenBoston: Brill.

Lambert, P.-Y., 2003, La langue gauloise, $2^{\text {nd }}$ ed., Paris: Errance.

Meyer-Lübke, W., 1935, Romanisches etymologisches Wörterbuch, Heidelberg: Winter.

Much, R., 1897, 'Die Städte in der Germania des Ptolemäus', in: Zeitschrift für deutsche Altertumskunde 41, 97-143.

Nobbe, C. F. A., ed., 1966, Claudii Ptolemaei Geographia, Hildesheim: Olms.

Orel, V., 2003, A Handbook of Germanic Etymology, Leiden-Boston: Brill.

Pliny - see Winkler 1988.

Pokorny, J., 1959, Indogermanisches etymologisches Wörterbuch, BonnMünchen: Francke.

Schwarz, E., 1931, Die Ortsnamen der Sudetenländer als Geschichtsquelle, München-Berlin: Oldenbourg.

Schönfeld, M. 1911, Wörterbuch der altgermanischen Personen- und Völkernamen. Heidelberg: Winter.

Šimek, E., 1930, Velká Germanie Klaudia Ptolemaia [Germania Magna of Claudius Ptolemy], Vol. 1, Praha: Charles University, Faculty of Arts (in commission by F. Rivnáč).

Šimek, E., 1935, Velká Germanie Klaudia Ptolemaia [Germania Magna of Claudius Ptolemy], Vol. 2, Brno: Spisy FF MU 40 [Works of the Faculty of Arts of Masaryk University].

Šimek, E., 1949, Velká Germanie Klaudia Ptolemaia [Germania Magna of Claudius Ptolemy], Vol. 3, Brno: Spisy FF MU 47 Works of the Faculty of Arts of Masaryk University.

Sims-Williams, P., 2006, Ancient Celtic Place-Names in Europe and Asia Minor, Oxford-Boston: Publications of the Philological Society, 39. 
Stokes, W. \& Bezzenberger, A., 1894, Urkeltischer Sprachschatz, Göttingen: Vandenhoeck \& Ruprecht.

Toporov, V.N., 1980, Прусский язык [Old Prussian language] 3 (I-K). Moskva: Nauka.

Vries, J. de, 1962, Altnordisches etymologisches Wörterbuch, Leiden: Brill.

Winkler, G., 1988, C. Plinii Secundi Naturalis Historiae Libri III/IV, Darmstadt: Wissenschaftliche Buchgesellschaft.

\section{Acknowledgement}

The present study was prepared thanks to the grants of The Czech Science Foundation (GAČR), P406/12/0655 \& GA15-12215S. I am grateful to John D. Bengtson for correcting the English. 